\title{
Enamelling on Gold
}

\author{
A HISTORICAL PERSPECTIVE
}

\section{David Buckton}

The British Museum, London, U.K.

The revival of enamel has awakened interest in the history of the medium, as revealed by an increasing number of exhibitions, lectures and seminars on the subject. However, books and articles are rare, partly because of the expense of the necessary colour illustrations, and partly because the bistory of enamel is still being written - and will continue to be written for many years to come (l).

Enamel is essentially glass which, when heated to the point at which it melts, bonds to metal with which it is in contact. The product is stable, however, only when the glass and the metal are compatible, Because of differences between the coefficients of expansion of enamel and metal, stresses tend to develop in the system during cooling, and, to relieve or avoid them, careful annealing or counterenamelling (enamelling on the reverse side) is necessary in the case of some metals. However, these procedures may bẻ omitted with gold, which has consequently been preferred by enamellers for at least 3500 years. Even on a silver object, the enamel was often made separately, using a gold base (Figure 1).

\section{Variations of the Technique}

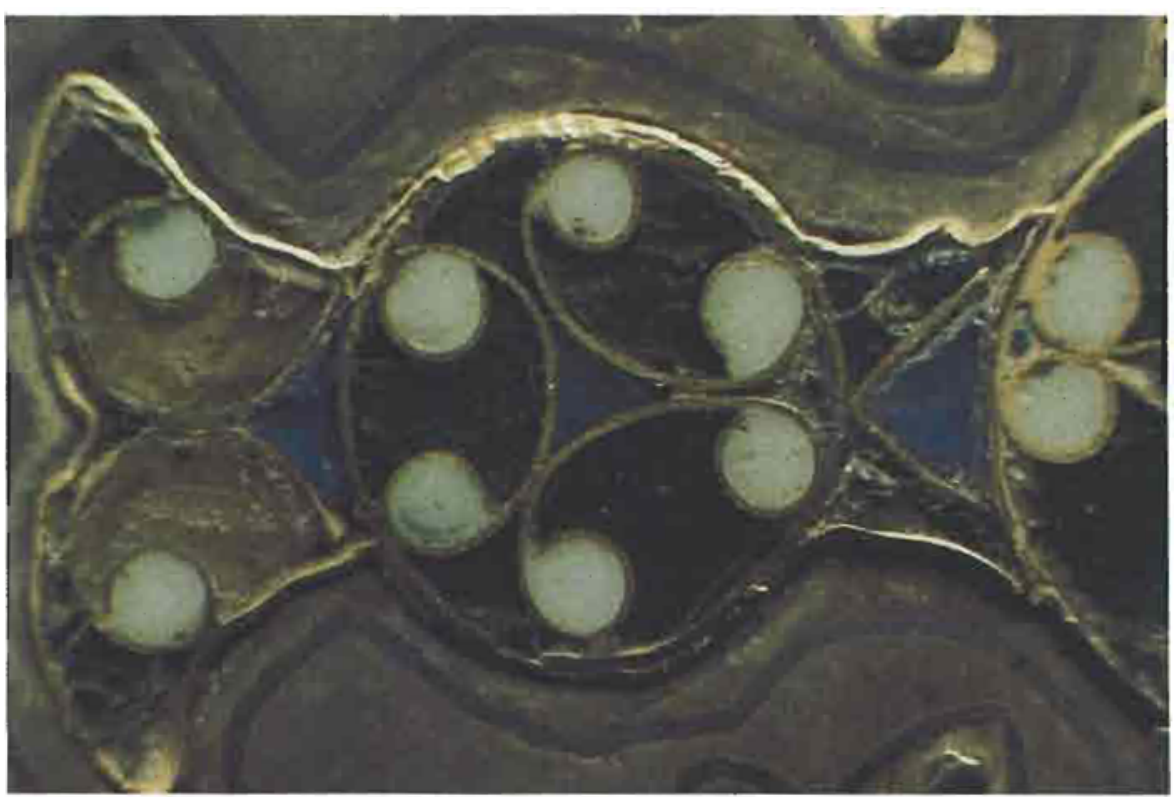

Fig. 1 Gold cloisonné enamel set in silver: portable altar from Adelhausen (detail), about A.D. 800 Photograpb: author, courtesy of the Augustinermuseum, Freiburg im Breisgau

The ways in which enamel is applied to metal can be divided into three categories. The first, in which the property possessed by enamel of fusing to metal as a laminate is exploited to the full, includes repoussé, ronde-bosse and painted enamel. The second, where the enamel is contained within metal boundaries perpendicular to the metal base, comprises cloisonné, filigree, champlevé and basse-taille enamel. The third, in which the only metal present is perpendicular to the plane of the enamel, consists of a jour enamelling and a form of cloisonné enamel which has no base-plate.

Repousse enamelling, one of the earliest known forms, is found on Minoan and Mycenaean jewellery of the late 15th and 14 th centuries B.C. Dark blue enamel was fused into

Fig. 2 Ronde.bosse enamel on gold: swan badge from Dunstable, early 15th: century A.D.

Pbotograph by courtesy of the Trustees of the British Museum, London

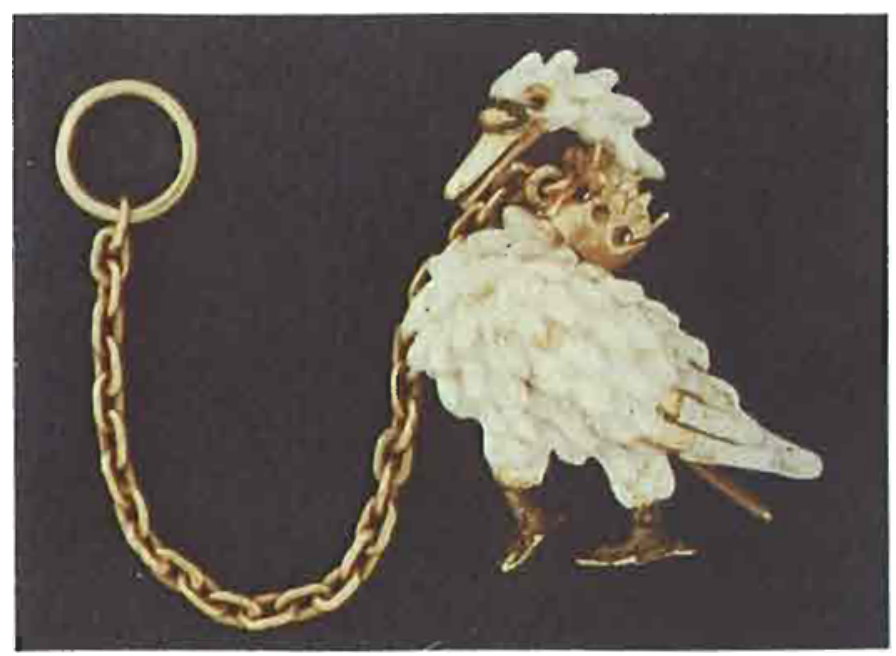


depressions embossed in gold sheet, usually ringed with granulation (tiny spheres of gold) (2). Ronde-bosse enamel, also called dipped or encrusted enamelling, is usually thought to have been invented in France towards the end of the 14th century A.D., but it was practised in the Greek world as early as the 3 rd century B.C. (3). A gold object would be enamelled 'in the round', usually in white, either by heating it and introducing it into molten glass or by painting it with a paste of glass and firing it (Figure 2). Painted enamel, the last major development in the history of the medium, evolved in the course of the 15 th century A.D. A scene or motif was painted in enamel on metal and fired.

Cloisonné enamelling, like repoussé practised in the Minoan-Mycenaean world from about 1425 B.C. (4), is characterized by a partitioning of the enamel with strips of metal (cloisons) soldered edge-on to the base-plate (Figure 11a). The technique was employed in Cyprus in the 12 th century B.C. (5), but there is little further sign of it until Roman times, when - particularly in the northern provinces - a tradition was established which eventually led to the outstanding gold cloisonné enamel of the early Middle Ages (Figures 1,6 to 10 and 12) and the Middle Byzantine Period, particularly the 11 th century A.D. Filigree enamel, often similar in appearance to repoussé enamel, was used in the early 6th century B.C. on Greek and, soon afterwards, on Etruscan jewellery (6). The technique eventually died out in the Byzantine world around A.D. 600, but it was rediscovered or re-invented in late 14 th century Venice and transmitted to Hungary in the 15 th century. The enamel was thinly applied inside loops of filigree wire soldered to the surface of the object. Champleve enamelling, involving gouging beds for the enamel in the surface of a metal plate (Figure 11b), was almost certainly a Celtic invention. An unbroken tradition in this technique ran through Roman times, the Migration Period, the Dark Ages and the early Middle Ages to reach its peak in the outstanding achievements of 12 th century craftsmen on the river Maas (Figure 3) and the lower Rhine. Basse-taille enamel, developed in Italy in the late 14 th century A.D. and widely practised in the 15th century, was a form of champleve in which the bed for the enamel was chased and engraved so that patterns and scenes would be visible through translucent enamel (Figure 4).

A jour enamel, sometimes known as Fensteremail, also involved the use of translucent enamel, this time to produce the effect of a miniature stained-glass window. The enamel had no metal back-plate and was fused only to an open framework of cloisons. Like basse-taille enamelling, émail de plique à jour - to give it its full name - was developed in the late 14 th and 15 th centuries A.D. Similar in technique to à jour enamel, a form of cloisonné enamelling employed as early as the 12th century B.C. (7) was still in use as late as A.D. 1000 (Figure 5). In this, an open network or grille of gold cloisons soldered together, was placed at the bottom of a mould and filled with ground glass of the desired colours; the mould was then topped up with glass of the chosen background colour and fired. The result was a glass plaque in one face of which was gold cloisonnê enamel.

Despite the superiority of gold as an enamelling base, the technique chosen could affect the choice of metal. The thickness of metal required for champlevé enamel (Figure 11b), for instance, favoured a cheaper metal such as copper, gold being reserved for gilding the metal parts exposed in the finished product. Gold dissolved in mercury was applied to the copper, the mercury subsequently being evaporated by gentle heat to leave the gold coating the surface. On the other hand, basse-taille enamelling, although also requiring a significant thickness of metal, depended for its effect on the reflection of light through translucent enamel, which called for a gold or silver base (Figure 4). Gold is the ideal base for translucent enamel, since no discolouring oxide layer forms at the interface between the glass and the metal. In the case of painted enamel, copper was preferred on the grounds of economy, unless the background plate was intended to contribute to the decorative effect, in which case a precious metal would be chosen.

Economics played an important role in the shaping of enamel history. Throughout the Dark Ages in northern Europe, for instance, enamel was conspicuously absent from aristocratic burials, which have instead yielded large quantities of gold and garnet cloisonné jewellery. There is some evidence that contemporary cloisonne enamel was the poor man's substitute for this jewellery, but when the supply of garnet began to dry up - towards the end of the 7th century A.D. - enamel gradually lost this stigma. In the time of Charlemagne (768-814) cnamel had begun to appear on objects principally decorated with garnet (Figure 6), eking out the more socially acceptable but dwindling decorative medium and at the same time being gently introduced to goldsmiths' aristocratic patrons. By the middle of the 9th century enamel had become so successfully established as a desirable decorative element that it appeared as the principal ornament on the high altar of Sant'Ambrogio, in Milan. The translucent enamel on this superb gold altar is fused in patterned gold beds reminiscent of the waffle-patterned reflectors of gold foil laid under garnet in Dark Age jewellery. This technique, adapted to enamelling on the Milan altar, anticipates basse-taille enamel, which was to be developed also in Italy - over four centuries later.

The high point of European cloisonné enamel was reached in the later 10th century A.D. (Figures 8 to 10 and 12), but an imminent change, this time from gold cloisonné enamel 
(Figure 7) to copper chumpleve (Figure 3) in the course of the 12th century, may again have owed more to economics than to changing fashion. For one thing, the development of Romanesque art marked a shift away from court workshops towards more local patronage, which may well have meant less money for individual works of art. More important, however, is the fact that no gold coinage was minted in Europe between 1000 and 1252 (8), which suggests that goldsmiths of the time were working with a disappearing commodity. Certainly, by the second half of the 12th century, gold was being employed sparingly, mainly for gilding. For example, the subsidiary figures on a Crucifixion plaque now in New York are executed in copper-gilt champlevé whereas, significantly, gold cloisonné was used for the principal figure, that of Christ (Figure 3). Once gold currency had been restored to Europe in 1252, gold cloisonné enamel enjoyed a remarkable revival - as the so-called émail de plique of the later 13th century - and the scene was set for the development of Gothic enamel, notably basse-taille, ronde-bosse and plique a jour.

We are fortunate in having a medieval text in part dealing with the craft of the goldsmith; those of us interested in enamel are doubly favoured by having in that one work, ' $D e$ Diversis Artibus' by Theophilus (9), a treatise on glass and step-by-step instructions for making a gold cloisonné enamel plaque.

In the context of the manufacture and ornamentation of a gold chalice, Theophilus describes the setting of stones and pearls and the preparation and soldering of the settings for the enamels (10). The sequence of operations which he implies - making the setting for the enamel before making the enamel itself - is initially surprising but, on reflection, logical. Spaces occupied by stones and pearls are dictated by the sizes and shapes of available stones and, less critically, pearls, whereas a still unmanufactured enamel plaque is almost infinitely adaptable. This adaptability can be seen on a 9th century brooch excavated in 1969 at the Carolingian port of Dorestad in the Rhine delta: the more adaptable medium, gold cloisonné enamel, fills the four irregular and unequal spaces left after setting the comparatively intransigent garnet (Figure 6).

\section{Preparing the Gold Base}

Theophilus gives instructions on how to make the gold base for the enamel by carefully cutting a piece of gold sheet to fit the prepared setting, removing it for use as the actual base-plate of the enamel and then soldering to it strips of gold sheet to form the edge of the plaque and the internal cellwork (Figure 11a) (11). In practice, however, the soldered base has never been popular with enamellers, because gases generated in the solder escape through the enamel during firing, leaving unsightly holes. These 'blow-holes' can also be made by steam from the moist glass and, of course, by gases from the solder of the cellwork, but it makes sense to limit soldering to the minimum. Therefore, a base such as that described by Theophilus is usually formed by bending the edges of the base-plate to create a perpendicular retaining wall (Figure 11c).

Other techniques found in early medieval gold cloisonné enamel bases include those using two sheets of metal to achieve the desired tesult. One method consists in sawing the required shape out of a sheet of gold, which is then provided with a flat back-plate (Figure 11d), the depth of the enamel being dictated by the thickness of the top sheet. This cut-out technique is typical of work produced in the early 12 th century at Conques, in southern Erance (Figure 7). Another method comprises the deformation of a gold top plate into a cavity sawn out of a bottom plate, creating a seamless receptacle (Figure 11e), the depth of the enamel being dependent on the thickness of the bottom sheet. This cut-out and embossed technique was used for some of the finest examples of gold cloisonné enamel of the last quarter of the 10th century, which were made for Archbishop Egbert of Trier $(977$ - 993).

Where the base was made from a single sheet of gold, it was frequently deformed to create the required receptacle (Figure 11f). This is the embossed technique characteristic of Byzantine enamel from the 10th century onwards, which was in use in northern Europe by the year 1000 (Figure 9). The enamel could be given a sharper edge by the provision of a cut-out top plate (Figure 11g), and this double-sheet base was common from the 10th century, both in Byzantium and northern Europe (Figure 10). Certain features of the British Museum medallion illustrated here are not apparent from the back of the plaque. The inscription, for example, was cut through the thickness of the top plate without provision being made for it in the embossed bottom plate.

Occasionally the bed for the enamel would be gouged out of a gold plate - in effect this was champleve (Figure 11h) and gold cloisons added to produce a champlevé-cloisonné hybrid. The most notable examples of enamels made by this method are those on the imperial crown in Vienna, which was probably made for a coronation in 962 (Figure 12).

\section{The Enamel}

The next stage described by Theophilus involves the raw material for the enamel itself. Ready-made glass of various colours is assembled, and a sample of each colour tested for compatibility. Any glass which melts too readily or, presumably, at too high a temperature to be used with the others is discarded. Glass which has passed the test is heated, one colour at a time, and dropped into cold water, 


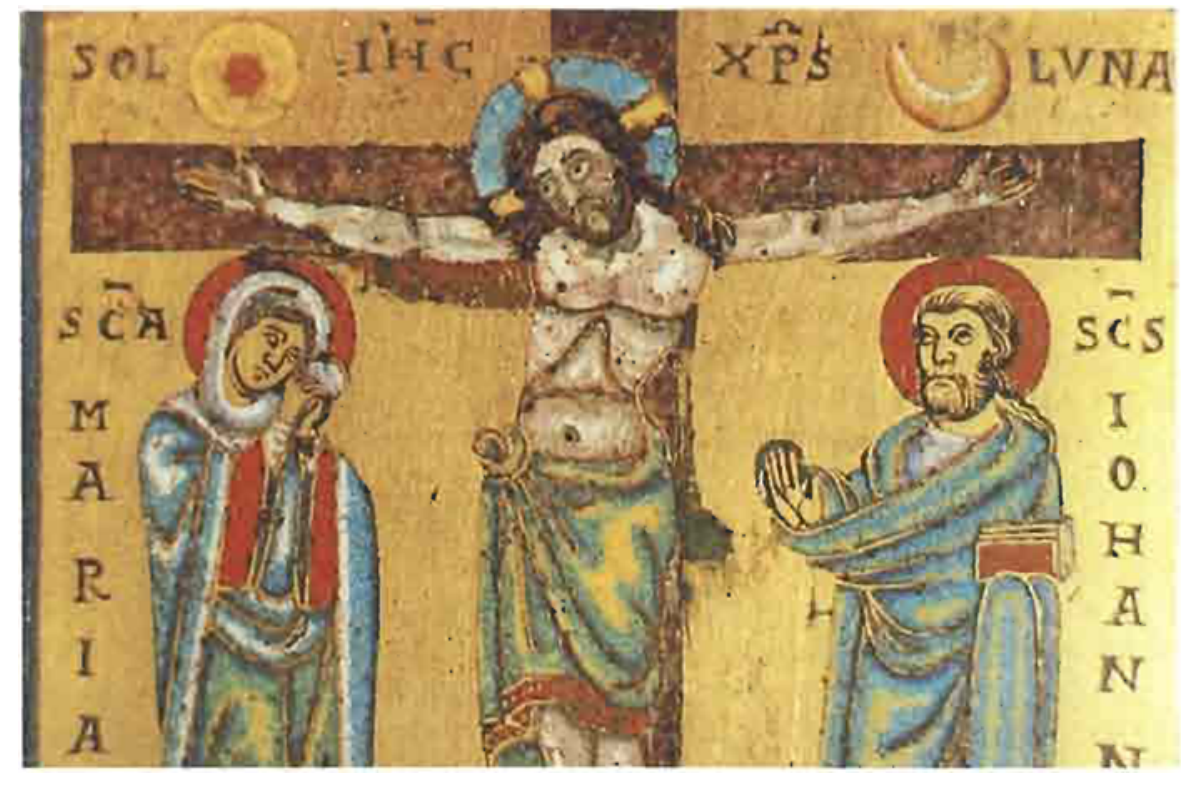

Fig. 3 Copper-gilt champleve enamel with the figure of Christ in gold cloisonné (detail), 12th century A.D.

Pholograph: anthor, courtesy of the Metropolitan Musewm of Art, New York

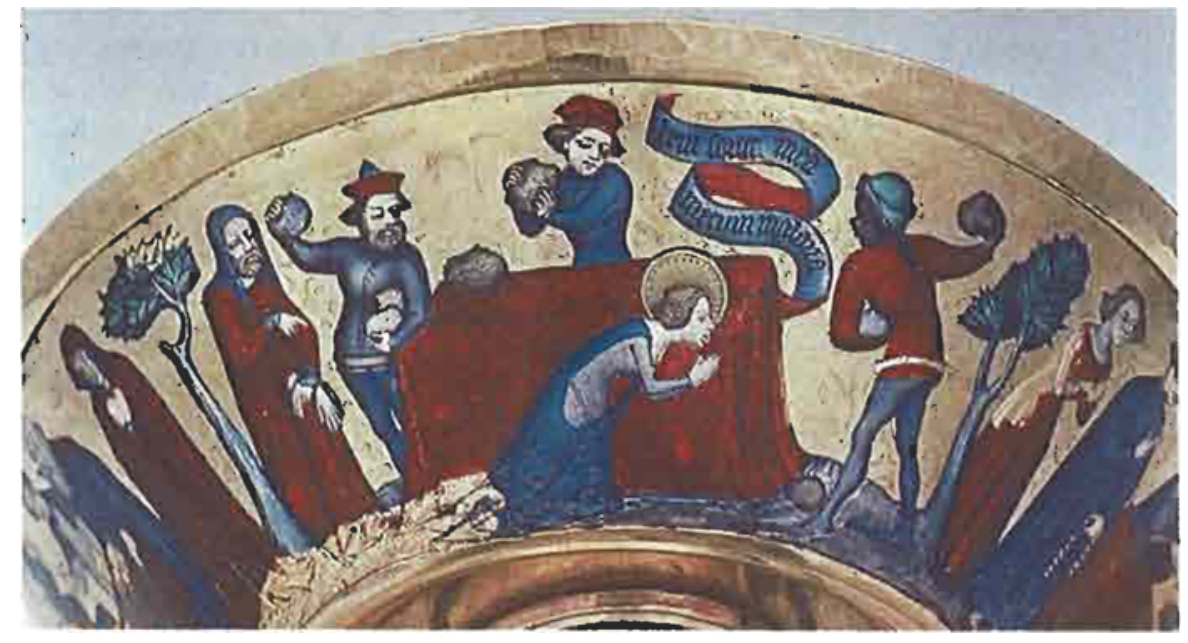

Fig. 4 Basse-taille enamel on gold: the Royal Gold Cup (detail), about A.D. 1380

Photograph by courtesy of the Trustees of the British Museum, London

Fig. 5 Gold cloisonné enamel made without base (front and back): fragment, about A.D. 1000

Photograph: author, courtesy of the Trustees of the British Musseum, London
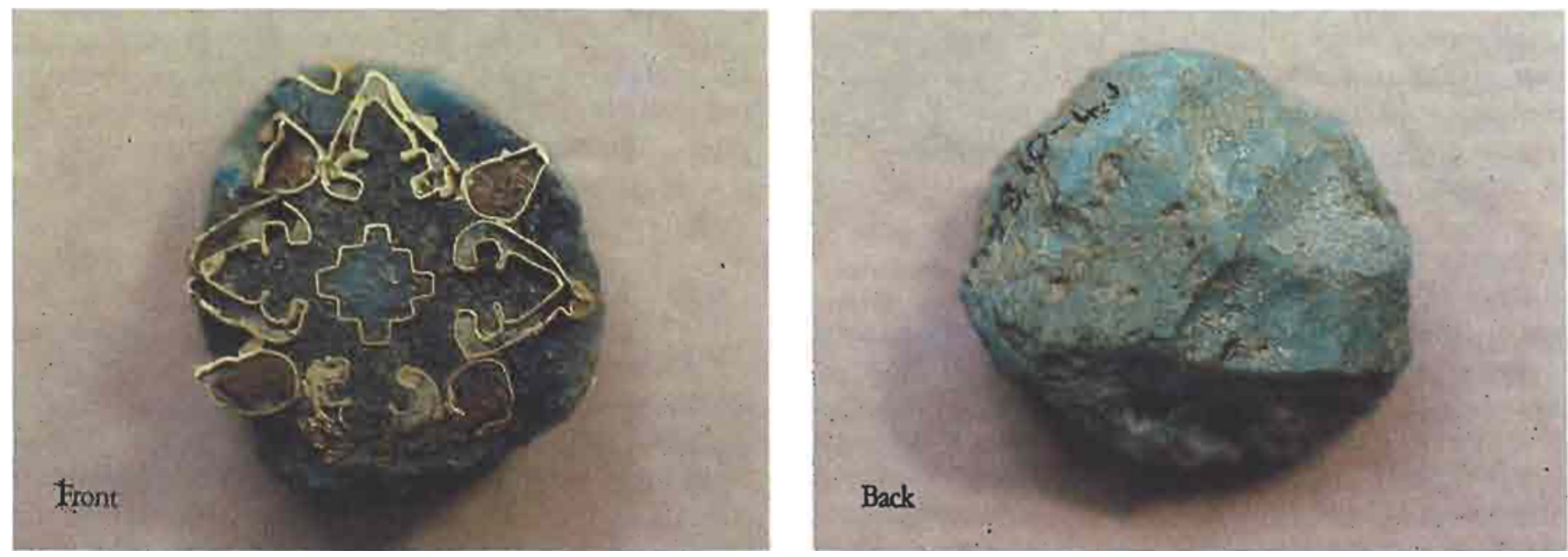
whereupon it fragments. It is ground with pestle and mortar, washed and stored for use (12).

According to Theophilus then, the early medieval enameller's raw material was ready-made coloured glass, the palette being restricted only by the compatibility of melting ranges and, of course, by availability. Analyses carried out on opaque early medieval enamel in the British Museum, however, have unexpectedly shown the presence of compounds of antimony. It is generally believed that the use of antimonates to opacify glass was abandoned by the 4 th century A.D. and not resumed until the late Middle Ages, and that antimonates were replaced by compounds of tin during the intervening period (13).

The presence of antimonates in early medieval enamel can be interpreted in three ways: first as casting doubt on the authenticity of the enamel (in which case much of the early medieval enamel in the British Museum is suspect), secondly as militating against the accepted chronology of the shift from antimonates to compounds of tin (although this would seem to be firmly established in respect of glass, as distinct from enamel), or thirdly as suggesting that the glass used for early medieval enamel had not undergone the shift from antimony to tin and was therefore different from normal contemporary glass.

This last interpretation has much to commend it, for, in his treatise on glass, Theophilus expressly describes the enameller's raw material:

'Various kinds of glass are found in mosaic work in ancient buildings of the pagans: white, black, green, yellow, blue, red, purple. They are not translucent, but opaque like marble; they are like little square stones, and from these enamels are made on gold, silver and copper ...' (14).

In other words, carly medieval enamel was made from ancient glass, already opacified with compounds of antimony before this practice was discarded in or before the 4th century A.D. Glass tesserae abound in Late Antique floor mosaics dating from before the development of Christian art in the 4th century, and it is clear that they constituted a ready source of glass in the early medieval world. They have been found on Scandinavian bead-making sites at Åhus in Sweden (15), Bornholm (15), Paviken (16), Birka (16), Ribe (16), Helgö (16) and Kaupang (16), and at Birsay on Orkney (16). When the art of mosaic in Rome was revived after a gap of almost a hundred years, at the end of the 8th century A.D., Late Antique tesserae were used (17). A letter from Pope Hadrian I (772 - 795) authorizing Charlemagne to remove mosaics from Ravenna is well known (18).

Another early medieval text, 'De Coloribus et Artibus Romanorum' by Heraclius, mentions the 'beautiful shining gems of every sort' which can be made from Roman glass (19), and Theophilus follows his remarks on glass tesserae from ancient sites with a reference to small vessels of the same colours which can also be found, and which the Franks (or the French), 'who are most skilled at this work', melt in their kilns, adding a little colourless glass to make 'precious sheets of blue, which are very useful for windows'. He goes on to say that they produce purple and green glass in the same fashion (20). It is significant that green, blue and purple are by far the commonest colours of translucent enamel.

The final stages in the manufacture of a gold cloisonne enamel plaque, as described by Theophilus, involve the filling of the cells with ground glass of the desired colours, the firing of the plaque, and cooling, washing, topping up and refiring, the cycle being repeated until the cells are filled to the top with enamel. Finally, the plaque is ground and polished with increasingly fine agents until 'if one half were wet and the other dry, no one could tell which was which' (21).

\section{Europe and Byzantium}

Although the Byzantine world, particularly Constantinople, is credited with preserving - if not evolving - the great tradition of gold cloisonné enamel, surviving evidence favours the goldsmiths of northern Europe as the heirs to the provincial Roman tradition, the Byzantines inheriting instead the filigree enamel of the ancient Greek world. No orthodox cloisonné enamel can be attributed unquestionably to the Byzantines before or during the long period of Iconoclasm, in which images were banned, and much of the inspiration for the sudden appearance of religious medallions and plaques in gold cloisonné enamel soon after the end of Iconoclasm in 843 must have come from northern Europe. There is some evidence that European goldsmiths were involved. Whether or not this drained the north of craftsmen, there followed a hundred-year gap in enamel production in Europe. When it reappeared, the gold cloisonné enamel looked so Byzantine that the debt had clearly been repaid by Constantinople to northern Europe (Figures 8 to 10 and 12).

Much more research is needed, into glass, enamel and the metal used as the base, before the history of enamelling can become more than a few tantalizing glimpses into the development of a fascinating craft. Analyses of Byzantine vessel glass and glass tesserae are rare. It seems inconceivable that Byzantine tesserae were not used by northern enamellers, but without the requisite data there can be no certainty. More analyses of the metal used as a base for enamelling are desirable. The preferred base in the early Middle Ages and the Middle Byzantine Period seems to have been 20 carat or finer gold, but more data would enable comparisons to be made, for example with contemporary Byzantine coinage, in an attempt to identify the source of the gold. 

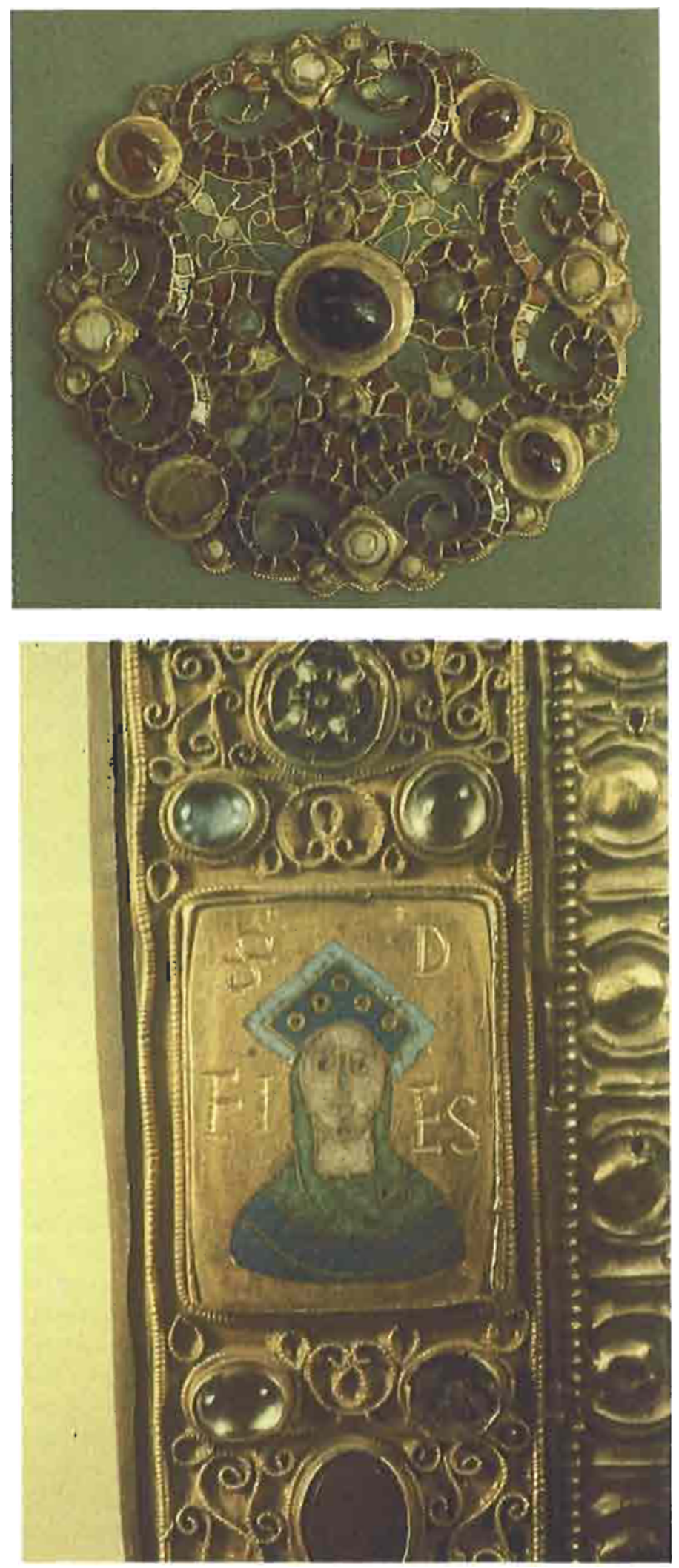

Fig. 6 Top left. Gold cloisonné enamel, with cold-set garnet, pearls and glass: gold brooch from Dorestad, early 9th century A.D., now in the Rijksmuseum van Oudheden, Leiden

Photograph: author, courtesy of the Rijksdienst voor bet Oudbeidkundig Bodemonderzoek, Amersfoort

Fig. 7 Bottom left. Gold cloisonné enamel: onyx portable altar (detail), early 12th century A.D.

Pbotograph by courtesy of the Treasury of Sainte-Foy, Conques-en-Rouergue

Fig. 8 Top right. Gold cloisonné enamel: portable altar and reliquary (detail), A.D. 977.993

Photograph; Dr. Franz Ronig, courtesy of the Bischoffiches Generalvikariat, Trier 

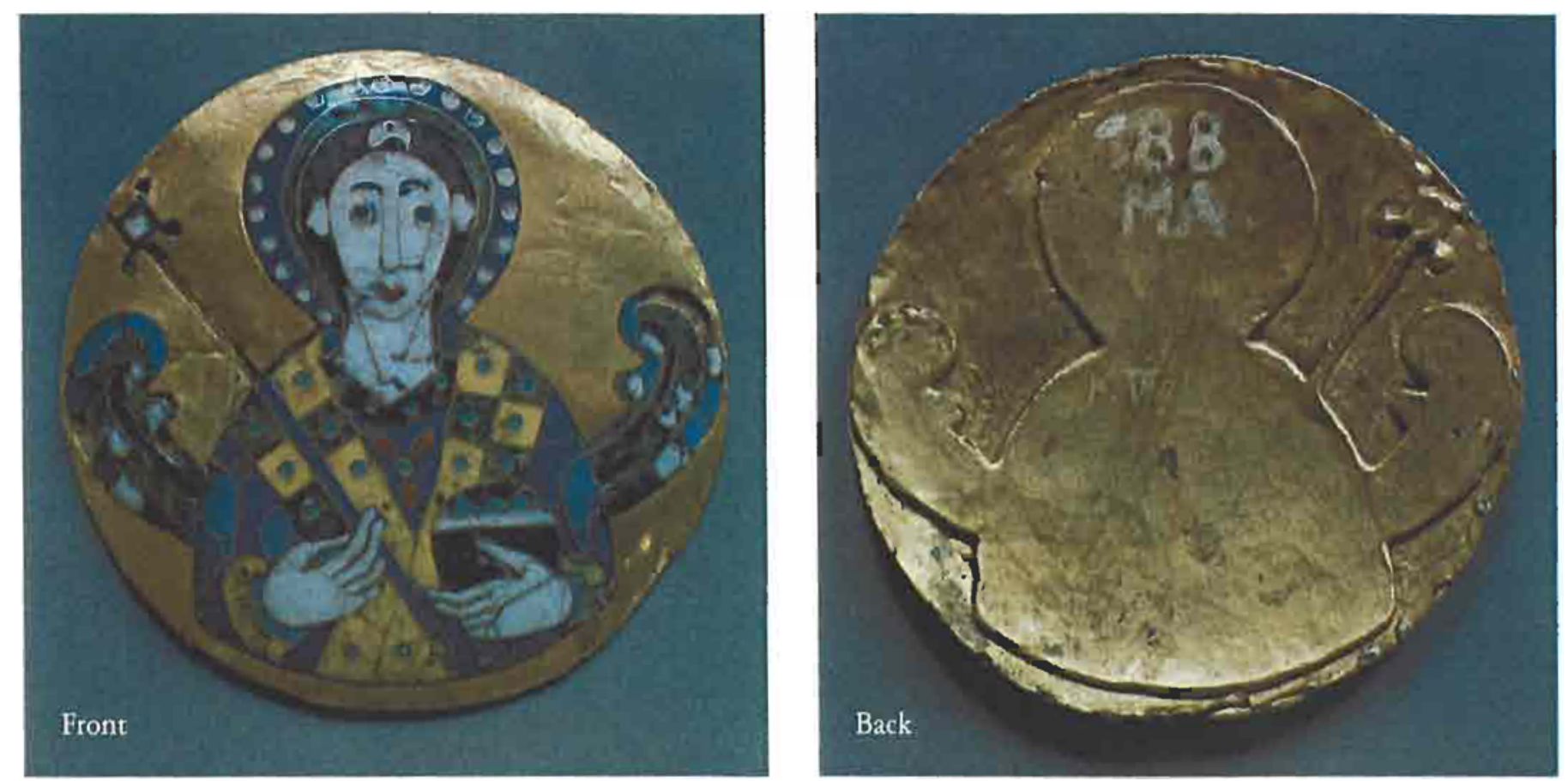

Fig. 9 Gold cloisonné enamel (front and back): medallion of archangel, about A.D. 1000 Photograph: author, courtesy of the Bayerisches Nationalmuseum, Munich

Fig. 10 Gold cloisonné enamel (front and back): medallion of Christ, about A.D. 1000 Pholograph by courtesy of the Trustees of the British Museum, London
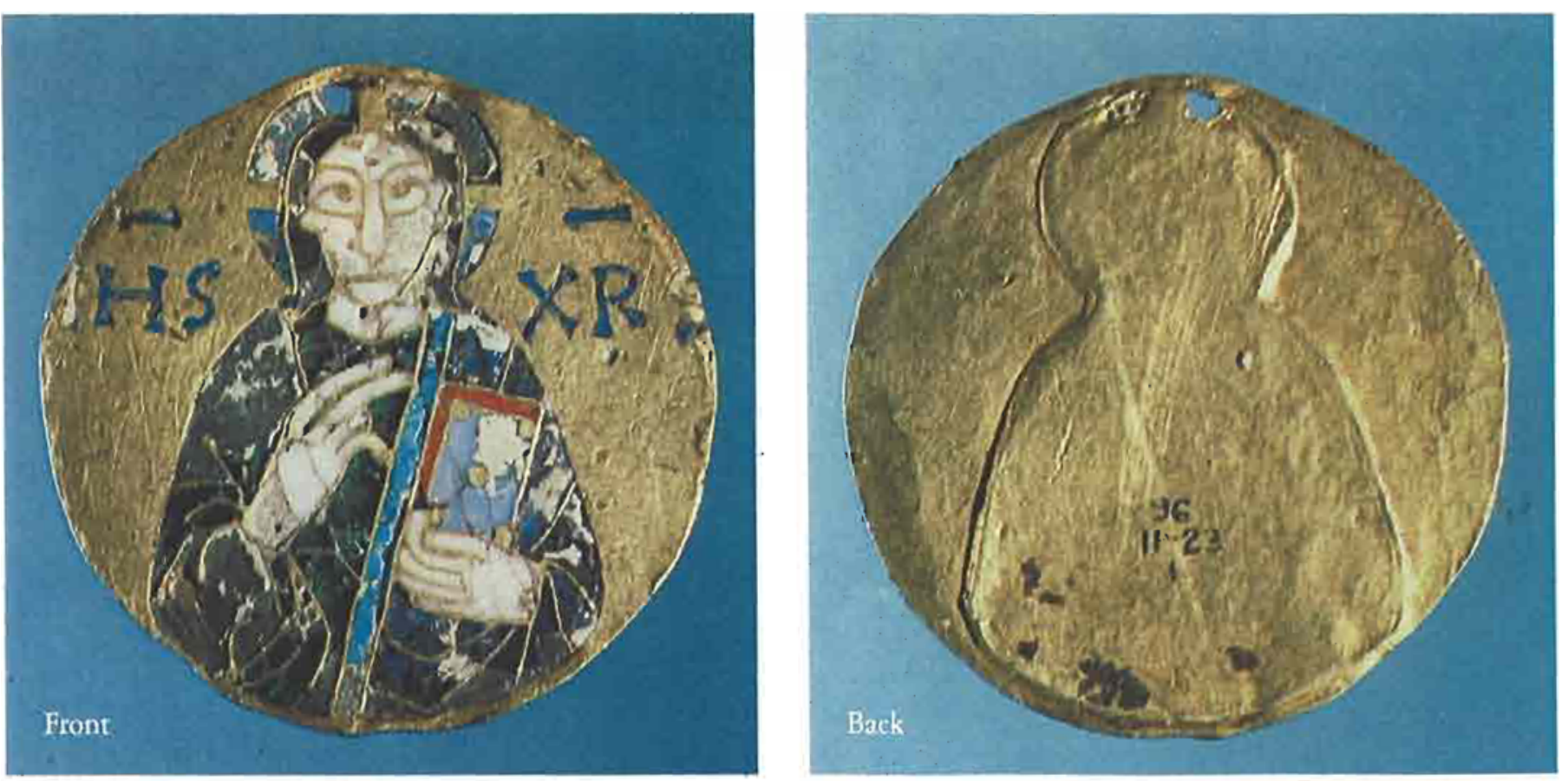

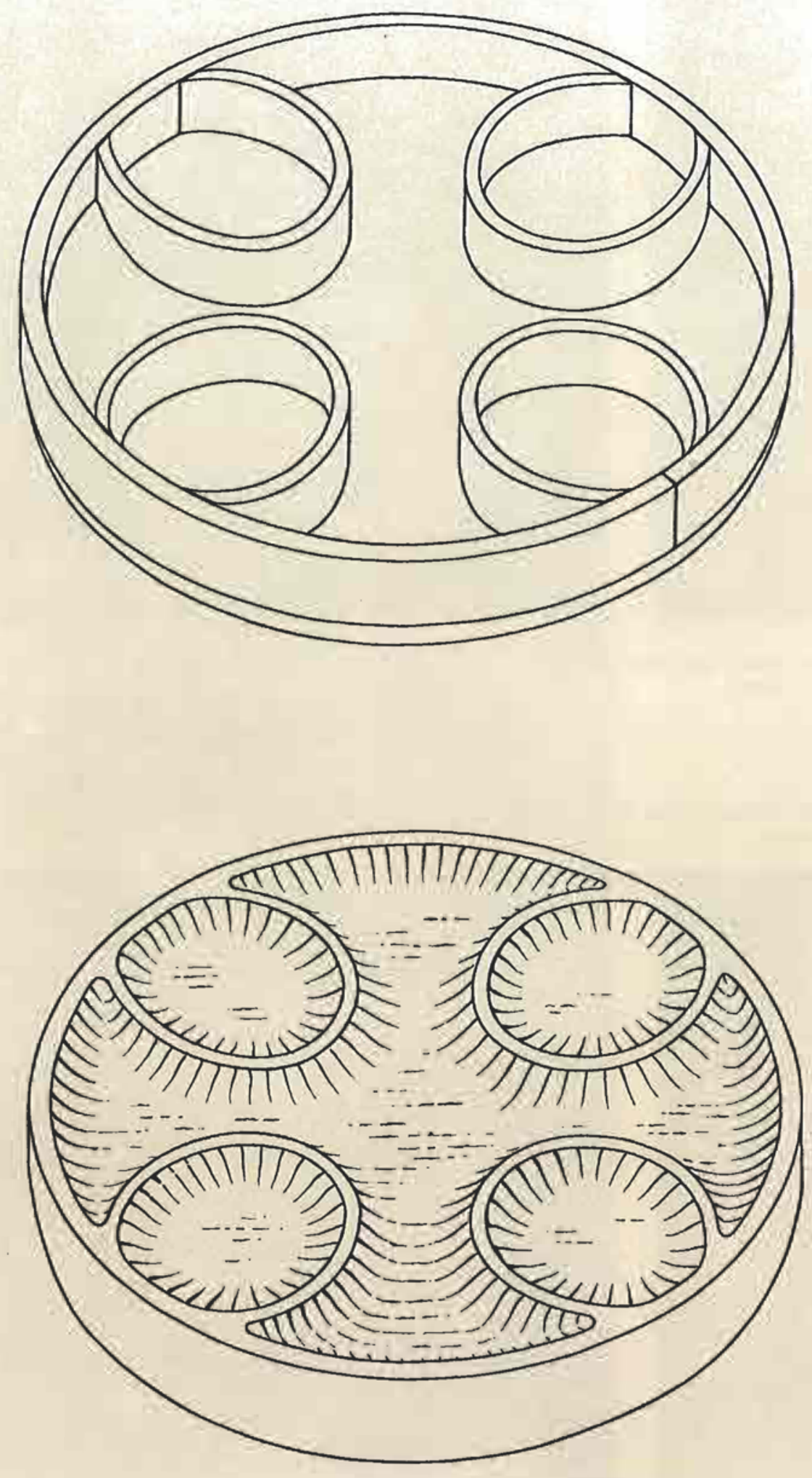

Fig. 11(a) Diagram of cloisonné enamel base. Drawing: David Goodger

Fig. 11(b) Diagram of champlevé enamel base. Drawing: David Goodger 


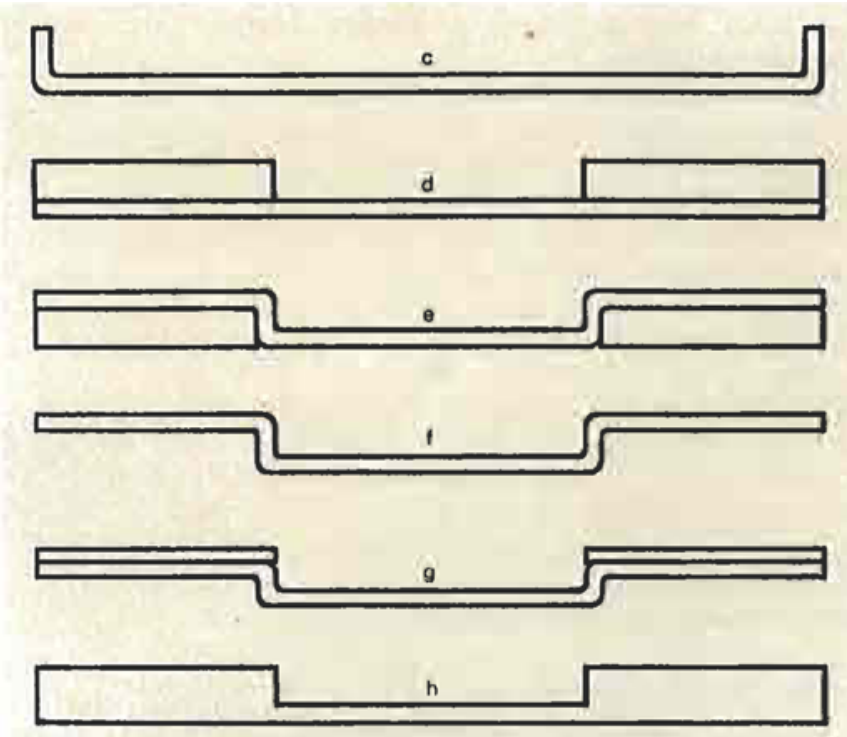

Fig. 11 ( $c$ to h) Diagrammatic cross-sections of gold cloisonné enamel bases discussed in this article

What is beyond doubt, however, is that enamelling on gold has been practised for three and a half thousand years and that it continues to provide an attractive medium of expression for artists and craftsmen. Goldsmiths all over the world are making cloisonné, filigree, champlevé and $a$ jour enamels on gold, witness the number of enamel exhibitions mounted during the past two or three years.

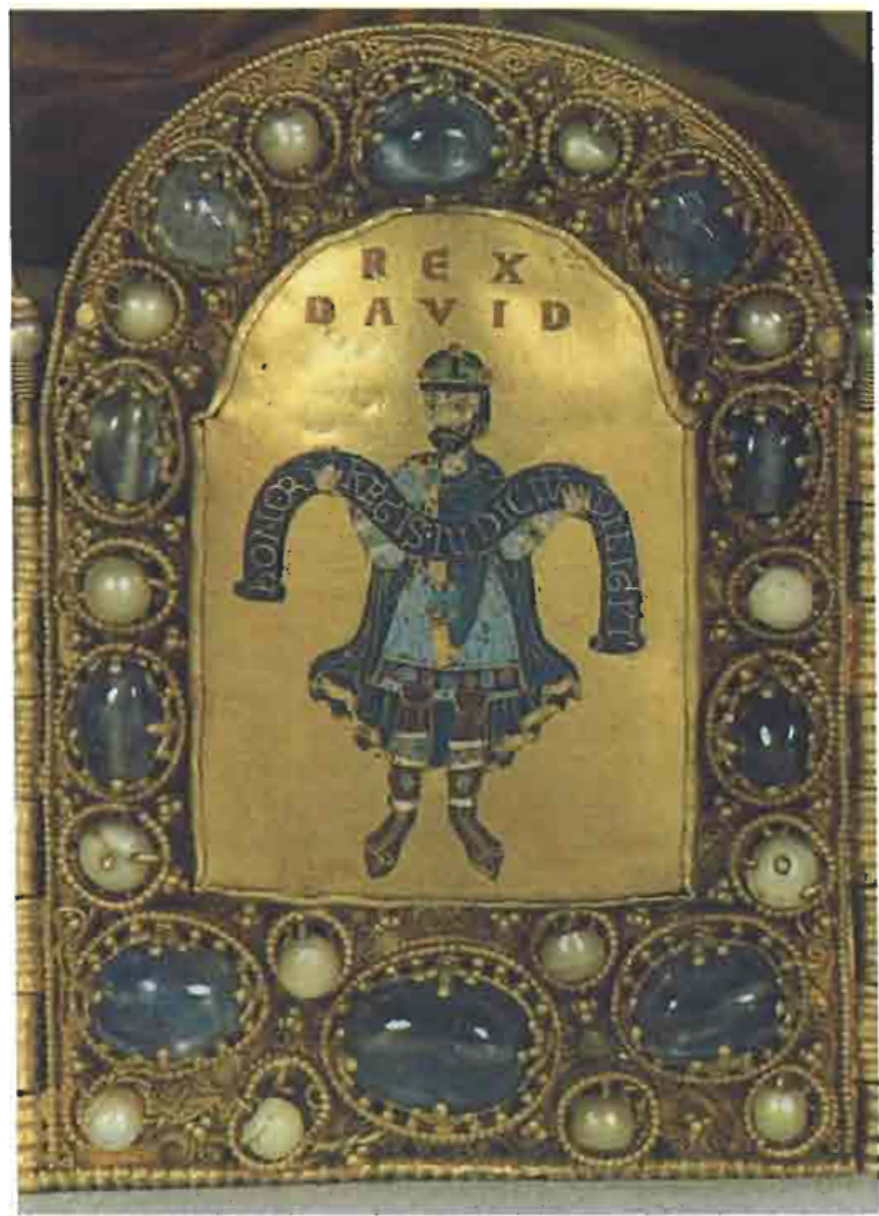

Fig. 12 Gold cloisonnê enamel: imperial crown (detail), probably A.D. 962 Photograph by courtesy of the Kunsthistorisches Museum, Vienna

\section{Notes and References}

1 While he unceservedly acknowledges, with gratitude, the authoritative help given by Mavis Bimson on enamel, by Andrew Oddy on gilding (both of the Department of Scientific Research and Conservation in the British Museum) and by Ernest Hawkins, OBE, on mosaics, the author wishes to make it clear that he is entirely responsible for the conclusions which he has drawn in this article.

2 R. Higgins, 'Greek and Roman Jewellery', 2nd Edition, Methuen and Co. Ltd., London, 1980, pp. 24-25

3 See (2), pp. 24-26, pl. 48B

4 See (2), pp. 24-25, pl. $11 \mathrm{~A}$

5 R. Higgins, 'Minoan and Mycenaean Art', Thames and Hudson Ltd., London, 1967, Fig. 222

6 See (2), pp. $24-25$

7 See (5), Fig. 223

8 A.M. Watson, Econ. Hist. Rev., 2nd Ser., 1967, 20, (2), I

J.P.C. Kent, personal communication

9 In the author's opinion the best edition is: C.R. Dodwell, 'Theophilus,

De Diversis Artibus', Thomas Nelson and Sons Ltd., London, 196

10 See (9), book III, chapter liii
11 See (9), book III, chapter liii. The different gauges of gold sheet and the internal border prescribed by Theophilus have been ignored in the interests of clarity

12 See (9), book III, chapter liiii

13 W.E.S. Turner and H.P. Rooksby, Jahrb. Röm. Ger. Zentralmus. Mainx, 1961, 8, 27

H.P. Rooksby, Gen, Electr. Co. J. Sci. Technol., 1962, 29, 20-26

14 See (9), book II, chapter xii

$15 \mathrm{~J}$. Callmer, personal communication

16 A. Lundström, Early Medieval Siudies, 1976, 9, 4-7

17 C. Davis-Weyer, in 'Fourth Annual Byzantine Studies Conference (Ann Arbor 1978), Abstracts of Papers', p. 4

18 'Codex Carolinus', letter 67, 'Monumenta Germaniae, Epistolae Merowingici el Karolini Aevi, I, 614)

19 M.P. Merrifield, 'Original Treatises, Dating from the XIIth to XVIIIth Centuries, on the Arts ...' vol, I, John Murray, London, 1849, pp. 182-257 for Heraclius, book I, chapter xiiii

20 See (9), book II, chapter $x$ il

21 See (9), book III, chapter lv 